\title{
Call for university expansion in West Germany
}

\section{Munich}

THE influential West German science council, the Wissenschaftsrat, has issued a stirring warning to the federal government (and to others who may be within earshot) that university investment should not be reduced. In its seventeenth annual "framework" plan on university construction, issued on 4 June, the Wissenschaftsrat seems to be especially alarmed at budget reductions planned by the federal finance ministry.

The influence of the Wissenschaftsrat derives from its constitutional status as the means by which the federal government, denied responsibility for research under its constitution, brings together other interested parties in executing an agreed policy. The Wissenschaftsrat includes representatives from federal and Land (state) governments as well as from industry and basic research. While its "framework plans" carry no official authority, they always serve as a strong guideline for policymakers.

This year's recommendations emphasize the need to finish the institutes and universities begun during the building boom of the $1970 \mathrm{~s}$. The Wissenschaftsrat also says that weak areas, such as clinical

\section{New AIDS drug}

\section{London}

BrITISH scientists who have discovered a new drug for the treatment of AIDS (acquired immune deficiency syndrome) and cancer are seeking financial support from a new company, Medirace, which is soon to be listed on the Stock Exchange.

The drug, called Contracon, is based on changes in the ratio of fatty acids in cell membranes associated with virus infections. Researchers say it seems to act by preventing cells from dividing, and by stopping the penetration or exit of the virus. The work has been met with scepticism by some other researchers, and so far there have been no clinical trials of the effect of the drug on AIDS.

Dr Kosta Apostolov, one of the team based at the Royal Postgraduate Medical School at Hammersmith Hospital, says initial research was funded "from our own pockets", but he says Australian and American backers have now promised about $\$ 1$ million for research and development work and clinical trials.

In answer to critics who say the team is jumping on the AIDS bandwagon he says, "it is just coincidence that we found these results at this time". Apostolov says the results of the research will be submitted to a medical journal shortly. Kathy Johnston research in medicine, need to be supported more strongly.

The pressure on medical faculties (and the increasing unemployment of physicians) should be eased by further reducing the numbers of freshman medical students by 25 per cent, according to the framework plan. And there is a need, the Wissenschaftsrat says, to invest more money in decentralized computers linked in networks among researchers and institutions

In sounding the call for a total of DM 9,300 million in university investment between 1988 and 1991, the Wissenschaftsrat pointed out that the universities are still enormously overburdened with students. Yet, the Wissenschaftsrat says, the amount spent on teaching and research remained constant, in real terms, between 1980 and 1985.

The timing of the recommendations is significant. The federal government is trying to find ways to cut its budget to allow for the tax reform planned for the years ahead, and the politicians in Bonn are well aware that the numbers of students at the universities and ochschulen are expected to decrease dramatically in the mid-1990s.

With its proposal to support more clinical research, the Wissenschaftsrat is attempting to fill a long-recognized gap in the West German research programme. Five additional research groups a year will be supported with DM 2 million each, so that by the fifth year the annual budget will be DM 25-30 million.

The call to reduce the number of medical students derives from a concern about a loss in quality as well as a (barely hidden) desire to reduce the number of doctors coming on the market. Under the West German constitution, the government is not allowed to manipulate the number of medical students based on the demand for doctors.

But because of excessive numbers of applicants, prospective medical students began to be judged on their school grades in the late $1960 \mathrm{~s}$. Further cuts could be made if it were shown that the number of students far exceeds the ability of institutions to teach them properly. Kurt-Jürgen Maass at the Wissenschaftsrat points out that the ration of medical students to beds in the teaching hospitals now amounts to 3:5 and that it is "much higher in some universities". In Maass' opinion, reducing the number of students by a quarter to a third would provide "entirely enough" doctors.

Such a decision would be welcomed by professional organizations; the Health Ministry is currently preparing a study to see whether the reduction is justified.

An official at the federal Education Ministry indicated that the 1988 federal budget, which will probably be hammered out by mid-July, should not reflect deep cuts in support for education. Achieving the DM 9,300 million recommended by 1991 is another matter. Steven Dickman

\section{Sex of new embryos known}

\section{London}

Two British medical teams have succeeded in identifying the sex and detecting hereditary diseases in newly fertilized embryos, raising moral and ethical questions.

The University of Edinburgh's in vitro fertilization (IVF) team has devised a test which uses a commercially available DNA probe to identify the male $\mathrm{Y}$ chromosomes in embryos $4-8$ days old. Seven human embryos were investigated, and 6 of these were positive for Y-chromosome DNA.

The Edinburgh team says the test could be used to test embryos obtained during in vitro fertilization treatment, or normally fertilized embryos collected by uterine flushing, and could lead to prenatal diagnosis of sex-linked genetic disorders.

Further research is necessary to perfect techniques to remove a single cell from the embryos, while using cryopreservation before implanting unaffected embryos into the mother's womb.

Gene probes are also being used to detect hereditary diseases in embryos by Professor Robert Winston and his team at London's Hammersmith Hospital IVF unit. Winston says he will be ready to apply the animal-tested technique to humans in "a matter of months", once he obtains approval from the local Ethics of Medical Research Committee and the Voluntary Licensing Authority.

A service to detect genetic disorders and hereditary diseases such as cystic fibrosis, haemophilia, muscular dystrophy and Down's syndrome is expected to be offered by a new $£ 250,000$ IVF clinic due to open at Hammersmith Hospital in October.

These successes of the two medical teams have led to reports in British newspapers that parents will soon be able to choose the sex of their test-tube babies, and speculation that it would be possible to change the sex composition of the population. But both teams deny that this is the intention. "Changing the population is not on", says Winston. A member of the Edinburgh team, Dr John West, says, "It certainly wouldn't be ethical to use the method to choose the sex of a baby. But", he admits, "we couldn't prevent the technique being used that way."

Kathy Johnston 